\title{
Morbillivirus neutralising antibodies in Scottish grey seals Halichoerus grypus: assessing the effects of the 1988 and 2002 PDV epizootics
}

\author{
P. P. Pomeroy ${ }^{1, *}$, J. A. Hammond ${ }^{1,2,4}$, A. J. Hall ${ }^{1}$, M. Lonergan, C. D. Duck ${ }^{1}$, \\ V. J. Smith ${ }^{2}$, H. Thompson ${ }^{3}$ \\ ${ }^{1}$ NERC Sea Mammal Research Unit, and ${ }^{2}$ Comparative Immunology Group, University of St. Andrews, \\ Gatty Marine Laboratory, St. Andrews, Fife KY16 8LB, UK \\ ${ }^{3}$ Department of Veterinary Pathology, Veterinary School, University of Glasgow, Bearsden, Glasgow G61 1QH, UK \\ ${ }^{4}$ Present address: Department of Structural Biology, Sherman-Fairchild Building, D159, 299 Campus Drive West, \\ Stanford University School of Medicine, Stanford, California 94305, USA
}

\begin{abstract}
Phocine distemper virus (PDV) may have killed a small number of grey seals Halichoerus grypus in European waters in 2002, as it was thought to have done in 1988. PDV is known to affect harbour seal population and distribution patterns, but grey seal pup production trends did not correlate consistently with PDV outbreaks. Numbers of known mothers missing from study colonies do not increase in PDV years and pre-weaning pup mortality is similar to that in other years. Pup growth rates are similar in PDV and non-PDV years. Therefore, no direct evidence links PDV outbreaks to changes in grey seal reproductive parameters at the population, colony, or individual level. Investigation of exposure of grey seals to PDV used CDV virus-neutralisation tests on sera collected from breeding seals pre-1988, 1988, 2001 and 2002. No positive sera ( $\geq$ titre 1:64) were detected prior to 1988. In 1988, 2001 and 2002 the prevalence was 96, 59 and $83 \%$, respectively. In 2001, prevalence in 'old' mothers (of breeding age by 1988, $\geq 13$ yr old) was $63 \%$ compared to $0 \%$ in 'young' mothers (born after 1989, <13 yr old). In 2002, prevalence was 88 and $93 \%$ in old and young mothers, respectively. Many pups were seropositive by the end of lactation (North Rona $=36 \%$, Isle of May = 54\%). Mean $\log _{10}$ antibody titres increased during lactation and were correlated with the mothers' titre. The high prevalence of seropositives in both adult age groups from geographically separated colonies suggests widespread exposure to a morbillivirus after 2001. This implies that PDV is highly infective and that contact was widespread before the 2002 breeding season.
\end{abstract}

KEY WORDS: Morbillivirus · Serology · Epizootic $\cdot$ Phocine distemper virus · PDV · Grey seals

\section{INTRODUCTION}

Northern Europe experienced a second major outbreak of phocine distemper virus (PDV) in 2002, largely among harbour seals Phoca vitulina (Jensen et al. 2002). Over 21000 carcasses washed up on the shores around the Kattegat/Skagerrak, Wadden Sea and North Sea between May and December (T. Härkö- nen et al. unpubl. data). The infective agent of PDV is a morbillivirus, a group that includes canine distemper (CDV), Rinderpest (RPV) and human measles. The first PDV cases in the United Kingdom were reported from the Wash (SE England) in July: by the end of December, 3854 seal carcasses had been found around the UK, of which $72 \%$ were in England. In the previous outbreak in 1988, 18000 dead seals were recorded 
from Europe, of which 3084 occurred in UK waters and approximately half were found in England (Hall et al. 1992).

In 1988 PDV had a dramatic effect on the abundance and distribution of UK harbour seals, with estimated mortality rates of up to $52 \%$ in areas such as the Wash on the east coast of England (Thompson et al. in press). By contrast, local mortality rates in 2002 were not as high, with the Wash experiencing <22\% mortality (Thompson et al. in press). These temporal and regional differences in harbour seal mortality have been attributed to different exposures and/or different immunity levels within local harbour seal populations (Lawson \& Jepson 2004).

Both recent PDV outbreaks in Europe have shown that many harbour seals die from the effects of PDV, but the conspecific grey seal Halichoerus grypus population appeared to be affected to a much lesser extent (Hall et al. 1992, Lawson \& Jepson 2004, T. Härkönen et al. unpubl. data). While most of the harbour seal deaths in England were found to be due to PDV, only half of the Scottish mortalities tested positive for PDV (by RT-PCR or immunoperoxidase test, England 63/69, $91 \%$; Scotland 6/12, 50\%; Lawson \& Jepson 2004). Similar findings were reported earlier from North America (Duignan et al. 1995a, 1997). Fewer than 10\% of reported seal mortalities during the 1988 and 2002 European PDV outbreaks were confirmed as grey seals, and many of these deaths were not PDV-related. Post mortem examinations of 72 grey seals in 2002 failed to find any that possessed classical PDV signs, even though 10 of these tested positive for PDV (Lawson \& Jepson 2004). Thus, even if a proportion of the grey seal population did acquire PDV infection, the effect of the virus was much less evident via direct mortality in grey seals than that in harbour seals. However, one of the first causes for concern at the start of the 1988 PDV outbreak was the unusually large number of abortions recorded among harbour seals at the Island of Anholt in the Kattegat, a characteristic of other morbillivirus infections (Dietz et al. 1989). As the 1988 outbreak coincided with the harbour seal breeding season and the disease's spread to the UK preceded the grey seal breeding season, early termination of pregnancy was a possible consequence for both species in the UK. No direct evidence of greater than normal numbers of abortions was recorded in grey seals in 1988. Nevertheless, in 1988 fewer known female grey seals were seen at the North Rona breeding colony than expected and adult female mortality was excluded because of the subsequent return to previous sighting levels in later years (Pomeroy et al. 1999). The temporary nature of any epizootic-related effect in grey seals is supported by the fact that independently assessed grey seal pup production in 1988 was lower than expected, and this observation was repeated at many other colonies (Harwood et al. 1991). If PDV infection causes early termination of pregnancy in grey seals, it might be expected that a similar phenomenon would be observed in resightings of female grey seals at breeding colonies in 2002 and 2003 and in estimates of pup production, as the timing of the disease outbreak in spring 2002 was similar to that in 1988.

Diagnosis of the disease in 1988 relied primarily on clinical signs and gross pathology, but by 2002 the availability of RT-PCR and immunoperoxidase methods allowed a more precise diagnosis of viral infection (J. A. Hammond et al. unpubl. data). Nevertheless, as a simpler, more direct and cheaper indicator of morbillivirus exposure, the CDV-neutralising antibody test (VNT) has proven extremely useful (Cornwell et al. 1992, Duignan et al. 1995a). Because PDV and CDV are so closely related, there is good agreement between results obtained with CDV-VNT compared to PDV-VNT ( 90\%, Duignan et al. 1995b). While most grey seals did not appear to succumb to overt PDV infection in either 1988 or 2002, serological examination of the grey seal population after the mass mortality events among harbour seals showed that most adult grey seals had antibody titres consistent with exposure to PDV in 1988 (Cornwell et al. 1992). Assessing exposure to the virus on the basis of serological evidence is complicated by the fact that, while seropositive harbour seals clearly had mounted an immunological response to infection, some harbour seals exhibiting clinical signs of PDV were seronegative. This is because during the early phase of infection animals are lymphopenic and immunosuppressed (Cornwell et al. 1992). Twelve months after the initial outbreak of disease, apparently healthy breeding grey seals tested in 1989 were almost uniformly seropositive. There is no information on how this exposure measure would decline, but it seems likely that, in the absence of further challenges, a slow reduction in the number of seropositives in the population could occur, similar to that found with other morbillivirus outbreaks (Cornwell et al. 1992). Few data have become available which would allow the level of susceptible seals or the immune status of seals to be determined. Thompson et al. (2002) used a cross-sectional approach to collect blood samples from Scottish harbour seals, and estimated that the proportion of previously exposed animals in 2002 was at best 9\%. However, the longevity of the antibody response in previously exposed individuals and the prevalence of susceptible unexposed individuals in the grey seal population had not been considered. The widespread exposure, absence of apparent signs and low mortality of grey seals in 1988 have focussed attention on the role of 
grey seals in PDV outbreaks. Although other potential sources and vectors of the virus have been suggested, the culprit has remained unclear (e.g. Blixenkrone-Møller et al. 1989).

Offshore islands in the north and west of Scotland form the main breeding areas of grey seals in Britain. Two grey seal breeding colonies, one in the Outer Hebrides (North Rona) and the other on Scotland's SE coast (Isle of May), have been the focus of long-term reproductive studies. If grey seals' exposure to PDV occurred only via infective harbour seals reaching the UK from Europe, as has been suggested, we might expect that grey seals on the NW coast of Scotland would have had less chance of exposure to the disease than those on Scotland's SE coast, as they were further away from the source of infection and likely to have had a lower contact rate with harbour seals. This would also depend on the timing of their exposure relative to the breeding season. However, if grey seals are acting as vectors of the disease, the epidemiological characteristics of the outbreak within the grey seal population might be quite different.

The objectives of the present study were to (1) examine the serological evidence of exposure to PDV in 2 breeding colonies of grey seals on the east and west coasts of Scotland, 3 to 4 mo after the 2002 epizootic had reached the UK, (2) examine the antibody response to the disease in mothers that were alive during the last outbreak in 1988 and in those that were born after it, and (3) determine the pre-weaning development of antibody response in suckling grey seal pups in 2002.

\section{MATERIALS AND METHODS}

Overall estimated population mortality. Overall mortality is described elsewhere (Lawson \& Jepson 2004). Briefly, seal carcasses washed ashore were reported to a coordinating centre at the Institute of Zoology (IoZ), London (Lawson \& Jepson 2004). As many as possible of these carcasses were examined by veterinary staff at the IoZ or the Scottish Agricultural College, Veterinary Investigation Centre, in Inverness. Samples of lung, spleen, lymph node and brain from freshly dead animals were examined for viral antigen using RT-PCR or immunoperoxidase methods (Lawson \& Jepson 2004).

Colony-scale pup production. The most accessible index of the breeding population parameters for UK grey seals Halichoerus grypus is the annual number of pups born at all major breeding sites (Hiby et al. 1996). Grey seal pup production has been estimated annually from counts of pups in a series of aerial surveys of all major UK breeding colonies using large format photographs taken from a fixed wing aircraft, a process which has given a standardised production estimate over the past $20 \mathrm{yr}$. Total pup production is obtained by summing individual colony estimates, allowing local and overall trends to be obtained.

Study colonies. North Rona $\left(59^{\circ} 06^{\prime} \mathrm{N}, 05^{\circ} 50^{\prime} \mathrm{W}\right)$ is a rocky island lying $65 \mathrm{~km}$ north of the Butt of Lewis and covering an area of about 120 ha. North Rona has been used as a breeding colony by grey seals at least since the 1880s, and the seals there have been the subjects of a long-term study of reproductive behaviour (Boyd \& Laws 1962, Pomeroy et al. 1999). Pup production peaked around 12 October in both years of this study, and the breeding season lasts for approximately $10 \mathrm{wk}$, with $96 \%$ of all pups born between 19 September and 29 October (Harwood et al. 1991). Annual pup production at North Rona, determined from aerial surveys, varied between 1600 and 1100 during the study (1988 to 2002), and has been relatively stable since 1995 (Hiby et al. 1996, Sea Mammal Research Unit unpubl. data).

The Isle of May $\left(56^{\circ} 11^{\prime} \mathrm{N}, 2^{\circ} 33^{\prime} \mathrm{W}\right)$ lies 5 nautical miles $(\sim 9.3 \mathrm{~km})$ offshore at the mouth of the Firth of Forth and measures 2.5 by $0.5 \mathrm{~km}$. During this study it had the largest pup production of any single island colony on the east coast of the UK (Hiby et al. 1996). The majority of pups (ca 70\%) are born on the northern part of the island, which is mainly flat-lying, low, broken rocky terrain, covering an area of about 6 ha. Few pups were born on the Isle of May until 1977, when around 30 pups were born (Eggeling 1985, Harwood \& Wylie 1987). Approximately 300 pups were produced in 1979, and pup production increased to 2133 by 2000 (Sea Mammal Research Unit unpubl. data). The breeding season extends from mid-October to early December, with a peak in pup production occurring around 5 November each year. The colony has been the subject of a long-term study of reproductive behaviour since 1987 .

Capture and sampling of study populations. In most British colonies, individual female grey seals spend 18 to $20 \mathrm{~d}$ ashore, during which time they bear and suckle pups, come into oestrus and are mated. The pup is weaned abruptly when the female returns to the sea (Hewer 1960, Fogden 1971). Seals sampled in this study were marked as breeding adults or as pups or were identified by their individual pelage patterns (Pomeroy et al. 1999, 2001, Redman et al. 2001). At North Rona all seals ashore in the study area were mapped daily and scanned for the presence of known mothers. The rest of the colony was surveyed at 4 to $5 \mathrm{~d}$ intervals. Pupping state of identified animals was assessed each day during routine observations from a hide overlooking the colony (Pomeroy et al. 1999). Locations of dead pups were recorded each day on 
fine-scale maps of the colony, making it possible to obtain an index of the number of deaths each year. On the Isle of May counts of adults and pups were obtained from a series of large-scale aerial photographs. Mothers were immobilised using a massspecific dose of Zoletil (Virbac), and blood samples were removed from the extradural vein of mothers and the hind flipper of pups. Serum was removed from clotted blood samples and stored at $-20^{\circ} \mathrm{C}$ until analysis. The age of adult females was determined either by reading artificial marks applied to them as pups or by counting cementum and dentine layers from a removed incisor tooth (Age Dynamics). Mothers were classified as either old or young at the time of an outbreak. In 2002, those alive in 1988/1989 and therefore likely to have been exposed during the 1988/1989 epizootic were old ( $\geq 13$ yr old), while those born after 1989 were young ( $<13$ yr old). For comparison, the same age criteria were applied to animals sampled during the first outbreak.

Pup growth rates were measured directly by weighing pups to the nearest $0.2 \mathrm{~kg}$ at each capture, usually $10 \mathrm{~d}$ apart. These were corrected for maternal size following the procedure in Pomeroy et al. (1999). A general linear model (GLM) of the pup growth rate at each breeding colony used maternal post partum mass (MPPM) as a covariate and year as a factor. All animal handling was carried out under UK Home Office licence.

PDV exposure in grey seals. In 2002, CDV virus-neutralisation tests were carried out on serum samples collected at the start and end of lactation from 52 and 57 grey seal mother/pup pairs at North Rona (Outer Hebrides) and the Isle of May (Firth of Forth), respectively. The VNT method is described in detail elsewhere (Thompson et al. 1992). Briefly, 4-fold dilutions of serum were prepared and incubated with fixed amounts of CDV, after which each was inoculated into 4 wells of Vero cells in microtitre plates. Plates were incubated for $3 \mathrm{~d}$ at $37^{\circ} \mathrm{C}$ and were well examined for the presence of the viral cytopathogenic effect, which occurs in the absence of neutralising antibody. The resulting titre was taken as the reciprocal of the dilution at which the proportion of wells infected is reduced from 4 to 2 . This method has been well validated for use in seal serum (Cornwell et al. 1992). Within-sample $\log _{10} \mathrm{CV}$ of the virus neutralisation test was $0.04(\mathrm{n}=7)$. Antibody levels compared for the same animal within years were considered to be the same unless they differed by at least 4 dilutions, and the lower value has been reported. Sera results reported by Cornwell et al. (1992) and performed using the same method have been included in some of our analyses.

Statistics. Most statistics were performed with SPPS v11.0. Tests of proportions were carried out using customised routines in $\mathrm{R}$ to determine the likelihood of obtaining a similar or more extreme result in 10000 iterations of a binomial expansion.

\section{RESULTS}

\section{Estimated mortality in the UK}

Although the total number of dead seals (of both species) reported in Scotland in 2002 was approximately $11 \%$ of the total reported in the UK (Table 1), most of the deaths reported in November 2002 were probably due to normal grey seal pup mortality during the breeding season and were not necessarily associated with PDV. Since $>90 \%$ of the UK grey Halichoerus grypus and harbour seal Phoca vitulina populations are found in Scotland ( 200000 individuals), this represents only approximately $0.2 \%$ of the total Scottish seal population. Relatively few individuals from the total were identified as grey seals $(<300)$, a similar number to that reported in 1988. Even in the unlikely event that all the carcasses that could not be identified to species because of decomposition were grey seals and all had died from PDV, this would still represent a low mortality rate in the population $(<0.3 \%)$.

\section{UK pup production}

Grey seal census data indicate that the UK population has been increasing at around $6 \%$ annually until recently (Fig. 1). The only years since 1984 in which the UK pup production fell were 1988, 1997, 1999 and 2002 , when decreases of $5.1,2.2,7.0$ and $3.1 \%$, respectively, were recorded (Fig. 2). However, in each of these years, decreases were not observed at all breeding colonies. Very different pup production figures were observed both temporally within single colonies and between single colonies and the larger region within which they are located (Fig. 2).

Table 1. Mortality of grey Halichoerus grypu and harbour seals Phoca vitulina in the UK, 2002/2003 (after Lawson \& Jepson 2004)

\begin{tabular}{|lrrrr|}
\hline Region & Grey & Harbour & Unknown & Total \\
\hline England & 64 & 383 & 2240 & 2687 \\
Scotland & 71 & 48 & 152 & 271 \\
Orkney \& Shetland & 44 & 7 & 37 & 88 \\
N. Ireland & 13 & 33 & 18 & 64 \\
Wales & 103 & 0 & 1 & 104 \\
Total & 295 & 471 & 2448 & 3214 \\
\hline
\end{tabular}



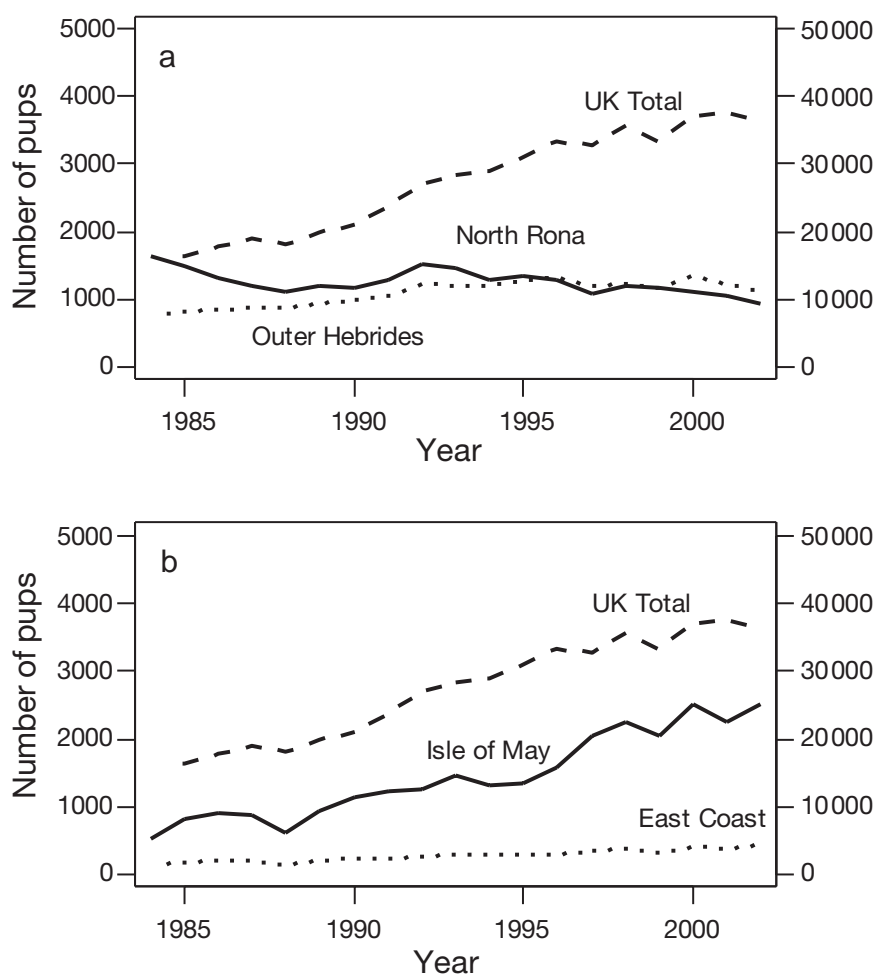

Fig. 1. Halichoerus grypus. Numbers of pups produced between 1984 and 2002: (a) at North Rona (solid line), at the Outer Hebrides (dotted line) and in the UK (dashed line); and (b) at the Isle of May (solid line), on the east coast (dotted line) and in the UK (dashed line). The primary $y$-axis is the scale for North Rona and the Isle of May; the secondary $y$-axis is the scale for the other populations

\section{Pup mortality at study colonies}

Direct pre-weaning pup mortality on North Rona $\left(\mathrm{NR}_{i}\right.$ estimated as the maximum number of dead pups as a proportion of the maximum number of females visible in the study area from the hide) was similar in 2002 to that of both 1997 and 1998 (20/310, 19/425, 31/430; $\mathrm{p}>0.3, \mathrm{p}>0.8$, respectively). The mortality rate of pups in aerial photographs of the Isle of May (IoM; estimated as the maximum count of dead pups as a proportion of total pup production) was lower in 2002 than in either 1997 or 1998 (160/2509, 171/2032, 250/2241; $\mathrm{p}<0.03, \mathrm{p}<0.001$, respectively).

\section{Skipped pupping years in known mothers}

In 1988, fewer known female grey seals were observed pupping on NR than expected from the numbers seen between 1985 and 1987, but the difference was not significant ( $p>0.4$, Table 2 ). There were more absences of mothers known to be alive in 2001 than
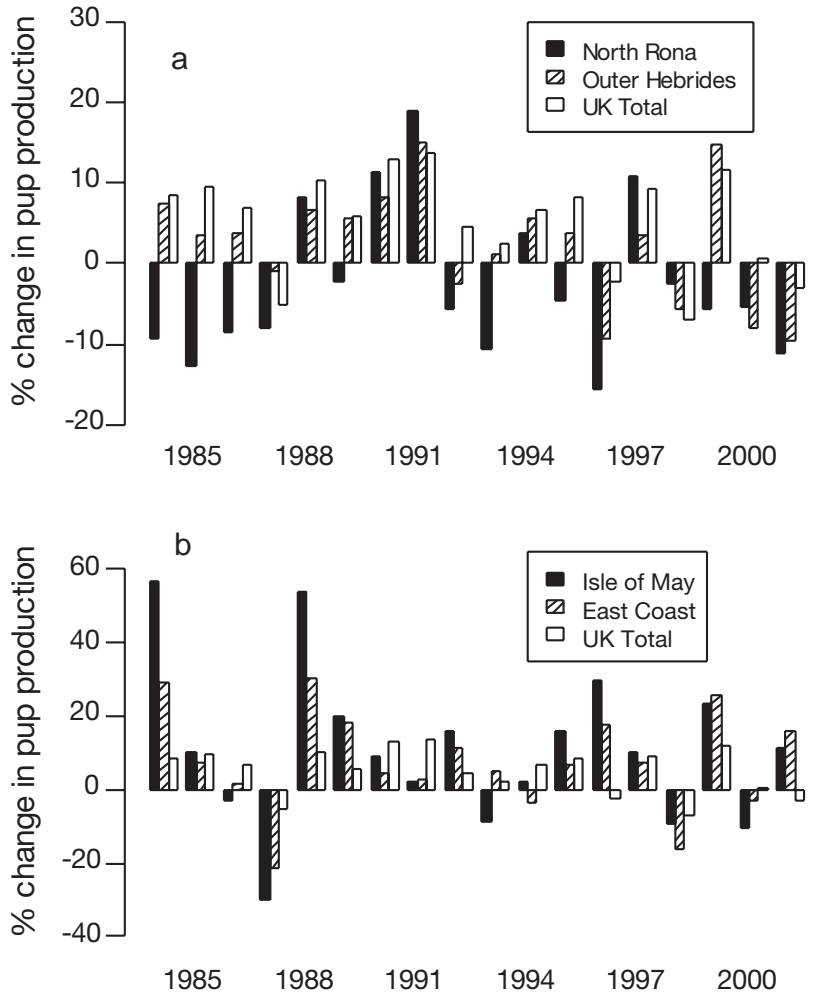

Fig. 2. Halichoerus grypus. Annual percentage changes in pup production at (a) North Rona and (b) the Isle of May, their

regions and the UK as a whole between 1984 and 2002

there were in 2002 at NR $(\mathrm{p}<0.01)$, but this could have been an artefact of photo-ID studies. Nevertheless, there was no evidence of unexpected absences of mothers at either study colony in the outbreak year of 2002 ( $p$ > 0.3), making unrecorded adult mortality very unlikely (Table 2). Proportionately fewer mothers on NR were absent in 2002 than in 1988 ( $p<0.001)$.

\section{Pup growth rate in disease years}

There were no differences in pup growth rates at either colony between years, after adjustment for

Table 2. Halichoerus grypus. Number of females known to be alive but missing from colonies in 2001 and 2002. The earlier data $(*)$ for North Rona refer to numbers of missing females from those expected to be alive, assuming annual mortality of 0.05

\begin{tabular}{|lcc|}
\hline Year & North Rona & Isle of May \\
\hline $1985-1987$ & $25 / 65^{*}(39 \%)$ & - \\
1988 & $32 / 64^{*}(50 \%)$ & - \\
2001 & $77 / 281(27 \%)$ & $17 / 68(25 \%)$ \\
2002 & $34 / 217(16 \%)$ & $7 / 57(12 \%)$ \\
\hline
\end{tabular}


MPPM (NR 2000 to $2002 F_{\text {year1,52 }}=1.88, \mathrm{p}=0.18$ : IoM 2000 to $2002 F_{\text {year } 2,85}=0.87, \mathrm{p}=0.42$ ).

\section{Prevalence of seropositive grey seals}

Archived sera collected at NR before 1988 showed no CDV-positive samples, using a threshold reciprocal antibody titre of 64 , with the highest titre of 48 recorded in 1987 (0/18, Table 3$)$.

The high level of seropositive animals in 1988 at NR $(94 \%)$ was similar between sexes ( $p>0.1$, pairwise comparison of samples from distributions, Table 3). None of the within-year differences between NR and IoM were significant ( $p>0.05$ ), but the proportions of seropositive seals in 2001 were significantly lower than in either of the 2 outbreak years (1988 and 2002). NR seals were less often seropositive in 2002 than in 1988, but the proportions in 1988 and 2002 were similar at the IoM ( $p<0.02$ and $p>0.05$, respectively; $p<0.005$ combined data).

Among old females, the proportions of animals that were still seropositive in 2001 were 14/28 at NR and 21/28 at IoM. By 2002 the corresponding figures were 29/34 and 30/33. Young females were seronegative without exception in 2001, but in 2002 young seropositives comprised 4/5 mothers at NR and 21/22 mothers at IoM. This was also reflected in the mean antibody titres recorded in these groups (Table 4).

\section{Changes in antibody titres with time}

Mean log-transformed antibody titres amongst sampled mothers at NR and IoM followed similar trajectories over time. By 2001, mean antibody levels had declined by almost an order of magnitude from their 1988 levels (Fig. 3). Three months after PDV was reported in the UK in 2002, grey seal maternal antibody levels had increased to levels similar to those seen in 1988. However, there was variation between the colonies and years. Differences in antibody response in the 2 outbreak years were investigated using a GLM of $\log _{10}$-transformed antibody levels measured at NR and the IoM in 1988 and 2002. The main difference was that average antibody level was higher at the IoM than at NR, regardless of the year (IoM 2.46 \pm 0.065 , NR $2.07 \pm 0.051$, mean $\pm S D, p<$ 0.001, Fig. 3).

\section{Seroconversion within years}

Comparison of antibody titres at the start and end of lactation in the same year was possible in 110 cases

Table 3. Halichoerus grypus. Number of seropositive adult grey seals at North Rona (NR) and the Isle of May (IoM) in phocine distemper virus epizootic and non-epizootic years. Females (F) and males (M) are differentiated as shown. See 'Results' for significant differences

\begin{tabular}{|c|c|c|c|c|c|c|c|}
\hline \multirow[t]{2}{*}{ Year } & \multirow[t]{2}{*}{ Gender } & \multicolumn{2}{|c|}{ NR } & \multicolumn{2}{|c|}{ IoM } & \multicolumn{2}{|c|}{ Combined } \\
\hline & & Positive & $\%$ (SE) & Positive & $\%(\mathrm{SE})$ & Positive & $\%(\mathrm{SE})$ \\
\hline Pre-1988 & $\mathrm{F}$ & $0 / 18$ & $0(0-18)$ & & & & \\
\hline 1988 & $\mathrm{M}$ & 9/11 & $82(52-94)$ & & & & \\
\hline & $\mathrm{F}$ & $38 / 39$ & $97(87-99)$ & $24 / 24$ & $100(84-100)$ & $62 / 63$ & $98(92-100)$ \\
\hline & All & $47 / 50$ & $94(84-98)$ & $24 / 24$ & $100(84-100)$ & $71 / 74$ & 96 (89-98) \\
\hline 2001 & $\mathrm{~F}$ & $22 / 41$ & $54(39-68)$ & $22 / 34$ & $65(48-78)$ & $44 / 75$ & $59(47-69)$ \\
\hline 2002 & $\mathrm{~F}$ & $40 / 52$ & $77(64-86)$ & $50 / 57$ & $88(77-94)$ & $90 / 109$ & $83(74-88)$ \\
\hline
\end{tabular}

Table 4. Halichoerus grypus. Mean canine distemper virus (CDV) antibody titres measured in adult grey seals at North Rona (NR) and the Isle of May (IoM) in the years preceding and during the first phocine distemper virus epizootic (1985 to 1987, 1988), and preceding and during the latest outbreaks $(2001,2002)$. Antilogs of the mean $\log _{10}$ CDV titres are shown with $95 \%$ confidence intervals in brackets. Seals were categorised as 'young' (up to $13 \mathrm{yr}$ ) or 'old' (13 yr or greater) at the time of sampling. Asterisks indicate a further 9 and 13 seals of unknown age were sampled at NR and 1 and 7 at IoM in 2001 and 2002, respectively

\begin{tabular}{|c|c|c|c|c|c|c|c|c|}
\hline \multirow[t]{2}{*}{ Year } & \multicolumn{4}{|c|}{ Young } & \multicolumn{4}{|c|}{ Old } \\
\hline & NR & $\mathrm{n}$ & IoM & $\mathrm{n}$ & NR & $\mathrm{n}$ & IoM & $\mathrm{n}$ \\
\hline 1985-1987 & $16(3,81)$ & 2 & No samples & - & $23(7,73)$ & 4 & No samples & - \\
\hline 1988 & $471(170,1303)$ & 4 & $268(136,528)$ & 9 & $295(150,581)$ & 9 & $337(152,711)$ & 7 \\
\hline $2001^{*}$ & $13(4,41)$ & 4 & $23(8,63)$ & 5 & $42(28,62)$ & 28 & $88(58,134)$ & 28 \\
\hline $2002^{*}$ & $108(47,247)$ & 5 & $352(232,532)$ & 22 & $112(79,159)$ & 34 & $143(98,208)$ & 33 \\
\hline
\end{tabular}




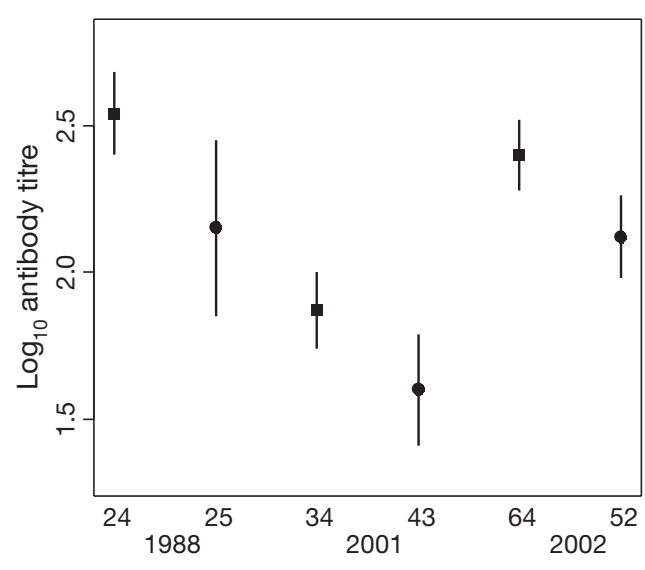

Fig. 3. Halichoerus grypus. Mean $\left(\log _{10}\right)$ antibody titres measured in adult female grey seals from North Rona (匹) and the Isle of May $(\bullet)$. Number of samples in each group is given below the $x$-axis

from the years 2001 and 2002. None of the 19 young mothers examined seroconverted (went from seronegative to seropositive). Of the 91 older mothers, 14 changed status during lactation, but only 5 of these involved a change in titres of more than a factor of 2 . At NR 1 animal in each year (2001 and 2002) increased titres from 32 to 91 . The titres of 3 mothers at the IoM decreased during 2002; titres dropped from 128 to 45 or 32 .

\section{Morbillivirus antibodies in grey seal pups}

Serum samples for pups in 1988 were not available, but in 1989 antibody titres measured in serum samples collected from 15 mother-pup pairs on NR suggested that maternal and pup antibody titres were correlated (Pearson's $\mathrm{r}=0.652, \mathrm{n}=15, \mathrm{p}<0.01$ ). However, this limited sample was composed of single samples from early and late lactation as well as postweaning pups. More extensive samples collected from lactating mothers and their pups in 2002 indicated that pup antibody

Table 5. Halichoerus grypus. Number of seropositive grey seal pups (reciprocal canine distemper virus-neutralising titre 1:64 or greater) in early and late lactation at North Rona and the Isle of May, 2002

\begin{tabular}{|lccc|}
\hline & All samples & North Rona & Isle of May \\
\hline $\begin{array}{l}\text { Early lactation } \\
\text { (pups aged 1-9 d) }\end{array}$ & $33 / 95$ & $18 / 47$ & $15 / 48$ \\
Late lactation & $48 / 71$ & $(38 \%)$ & $(31 \%)$ \\
(pups aged 10+ d) & $(68 \%)$ & $(66 \%)$ & $23 / 33$ \\
& & $(70 \%)$ & \\
\hline
\end{tabular}

levels increased as lactation progressed (Table 5), reaching around the same level as the mother's by the end of lactation. The proportion of seropositive pups increased from $1 / 3$ of pups in early lactation to $2 / 3$ of pups by late lactation (Table 5). Total maternal antibody level in late lactation was a significant predictor of pup antibody level (Fig. $4: \log _{10}$ pup CDV antibody $=0.43+$ $0.74 \log _{10}$ maternal antibody; $\mathrm{SE}=0.17$ and 0.08 , respectively, adjusted $\mathrm{R}^{2}=0.568, \mathrm{n}=71$ ).

\section{DISCUSSION}

\section{Mortality}

Although the number of carcasses found washed ashore give some indication of the extent of the disease outbreak, these are notoriously biased, because the species and origin of the carcasses are often unknown. Carcasses ascribed to a local harbour seal Phoca vitulina population may not have originated there, but simply have been deposited there by tides, prevailing winds, or current. Indeed 3 harbour seals tagged in the Netherlands were found on the east coast of England at the height of the 2002 outbreak (Lawson \& Jepson 2004). Carcasses reported from the more remote areas of Scotland were often not identified to species. Ultimately, the effects of such mortality on the population would depend on the age and sex of the fatalities. The effect on the population is also harder to measure in a species like grey seals Halichoerus grypus, because they disperse widely outside the breeding season (McConnell et al. 1999), and mortality cannot be easily attributed to a specific breeding population.

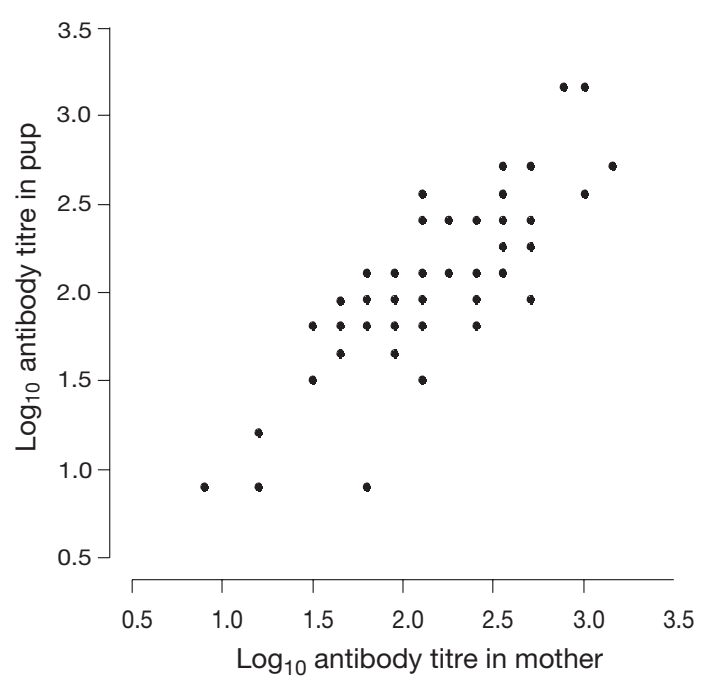

Fig. 4. Halichoerus grypus. Relationship between maternal and pup $\log _{10}$ antibody titre at the end of lactation 
Scottish harbour seal populations were much less affected by PDV in 2002 than their English conspecifics. PDV-positive seals were found dead all around the Scottish coast, including the Inner Hebrides, but the disease did not appear to reach the epidemic levels that were experienced in England. These intraspecific differences in the population-scale response to PDV between years may be due to local stochastic variation, differences in the virulence of PDV, or differences in the immunocompetence of different local groups due to genetic factors or contaminant exposure (Thompson \& Hall 1993, Hall 1995, T. Härkönen et al. unpubl. data, M. Lonergan et al. unpubl. data).

In 1988 there was an overall decrease in grey seal pup production in the UK, followed by a return to the previous trajectory, consistent with some undetected adult female mortality. At NR the decrease in the number of known animals seen in 1988 was temporary, and therefore not due to adult female mortality. No similar effect was seen in 2002 at either NR or the IoM. While pup production was lower at NR in 2002 than in 2001, the reverse was true at the IoM. Similarly our estimates of pup mortality in 2002 were either similar (NR) or lower (IoM) than those of previous years. It is therefore unlikely that the 2002 epizootic had a simple effect on parity or early mortality rates among grey seals.

The largest determinant of pup growth rates in grey seals is maternal size, estimated by MPPM (Pomeroy et al. 1999). There was no difference in the pup growth rates observed in disease and non-disease years after adjustment for maternal size. As most of the sampled mothers were seropositive in 2002, this implies that PDV-exposed mothers suffered no deterioration in their ability to feed pups, nor did the pups suffer any reduced ability to gain mass.

When grey seals have been infected with PDV they may remain asymptomatic (P. P. Pomeroy pers. obs.). None of the PDV-positive animals in this study displayed any unusual clinical signs. From the results obtained here, there is no evidence that PDV has demonstrable consistent effects on population, colony, or individual reproductive parameters.

\section{Antibody measurement}

We used CDV antibody titres to measure exposure of grey seals to the morbillivirus, mainly to allow direct comparison between results obtained after the 1988 epizootic and those derived more recently using the same test. The similarity of titres derived from the same samples run 13 yr apart was high, with no samples alternating between the seropositive and seronegative classification. This important result suggests that archived sera can be assayed for morbillivirus antibody status with some confidence. The close relationship between CDV and PDV and the cross-reactive nature of anti-CDV antibodies against PDV (Osterhaus \& Vedder 1988, Duignan et al. 1995a) indicated that the CDV virus-neutralisation test used for dogs would be sufficiently sensitive for the measurement of nonspecific morbillivirus antibodies in seals. This test was widely used for studying the response of seals to PDV during the 1988 outbreak, and, although homologous tests are now available (Duignan et al. 1994), we continued to use exactly the same CDV-VNT method, laboratory and analyst, in order to make direct comparisons between the results obtained at the time of the 1988 outbreak and those from 2002.

Mean antibody titres could decline in the population because either (1) this is a real temporal decline in individual titres, or (2) the seropositive animals remain at similar titres, but are 'diluted' by an increasing proportion of seronegative animals (those which either have not been challenged by the morbillivirus or have not mounted an antibody response to it). We found evidence of both effects.

Previously, serological evidence for the continued presence of PDV antibodies and their meaning in UK grey seals between epidemics has been confounded by methodological differences (Barrett et al. 1995, Hall 1995). Seropositive grey seals from the Farne Islands $(\mathrm{n}=75)$ were sampled in 1992 using a PDV ELISA assay. Results from 8 were compared with CDV-VNT, and all were negative, highlighting the difficulties in comparing results using different techniques. Indeed, Osterhaus et al. (1989) found 5 out of 30 harbour seals taken into a rehabilitation centre in the Netherlands between 1984 and 1988 contained low titres in a Rinderpest virus-neutralisation test; these were all negative with CDV-VNT. They suggested the absence of CDV-neutralising antibody, but the presence of some other morbillivirus antibodies in harbour seals prior to 1988 may indicate a qualitative difference in the types produced before and after the outbreak. The presence of morbillivirus antibodies in Arctic seal species prior to the first recorded European epizootic has been suggested as indicating the infective source and also a sufficiently large reservoir of susceptible seals (harp seal population size approximately 4 million) to maintain endemicity (Henderson et al. 1992, Ross et al. 1992). It is clear that PDV has been found in many Northern Hemisphere pinnipeds (Duignan et al. 1997). However, the identification of other types and strains of morbilliviruses in other marine mammals has complicated the picture.

Interpretation of antibody titres in relation to disease status is rarely straightforward. Initial exposure to PDV typically produces an increase in antibody production over a period of $16 \mathrm{~d}$. Cornwell et al. (1992) found that 
some harbour and grey seals with clinical disease signs never developed antibody titres as high as 1:64, presumably because of the immunosuppressive effects of morbilliviruses (e.g. McCullough et al. 1974, Mangi et al. 1976, Appel et al. 1982). Therefore, while high total antibody titres are characteristic of animals that have been exposed to the virus and mounted an immunological response, a low titre by itself cannot be interpreted as non-exposure to disease.

\section{Longevity of seropositivity}

The decline in morbillivirus titres measured in grey seals after initial exposure in 1988, followed by a rapid increase in titre after re-exposure, suggests a classical immunological response to challenge. Our results indicate that between $1 / 2$ and $3 / 4$ of adult female grey seals exposed to PDV in 1988 were still seropositive in 2001.

This is an important result for 2 reasons. First, this slow decline of antibody level in individuals confirms the indication that for many previously exposed seals, seropositivity and immunity extend over their adult lifetimes (female grey seals may reach ages in excess of 35 yr). Exposure to CDV can produce lifelong immunity in dogs (Krakowka et al. 1977), and probably a similar phenomenon occurs in grey seals. As a result, seropositive animals may be present in the population many years after initial exposure and are not simply indicators of 'recent' exposure (Duignan et al. 1995a). Second, the lack of seropositive seals in 2001 among those mothers born after 1989 suggests that most grey seals were not exposed to PDV in the period between 1988 and 2002. Similarly, we did not find any positive samples in those collected from grey seals prior to 1988, as reported previously (Harwood et al. 1989).

\section{Antibodies in grey seal pups}

Mothers pass some antibody to their pups via the placenta (immunoglobin class IgG) and colostrum or milk (first IgM then IgG) in the initial stages of lactation (Carter et al. 1992), although, as in dogs, this protection is not likely to be long-lived (Winters 1981). The capability for antibody production in grey seal pups develops during the first 2 wk of life while pups are suckling from their mothers, and it was during this period that increases in pup titres were observed here. Therefore, increases in antibody titres recorded for most pups during lactation in 2002 may have resulted from maternally derived antibody with a half life of around $8.5 \mathrm{~d}$ (Cornwell et al. 1992), development of immune function, a direct challenge to their immune systems, or a combination of the above. If maternal antibodies confer only partial or short-term immunity, this might explain the lack of seropositive young adults in 2002. CDV in dogs is capable of vertical transmission (Krakowka et al. 1977), particularly from bitches with subclinical infection, and PDV may behave in a similar manner in grey seal colonies if mothers were infective.

\section{Persistence, transmission and reoccurrence}

The absence of overt PDV from European harbour seals between 1988 and 2002 suggests that the disease is very unlikely to persist in this population, under current conditions. Preliminary analysis suggests that, for PDV to become a major threat to harbour seal populations, another species in close contact with them would have to regularly reinfect the majority of young susceptible animals (Swinton et al. 1998). Susceptible grey seals were infected sometime between the end of the 2001 breeding season and the beginning of the 2002 breeding season, as most mothers arrived at the colony as seropositives. Our results support the idea that PDV appears to be extremely infectious, but if like other morbilliviruses it is fragile, transmission must occur through close contact, for example via aerosol. It is remarkable then that so many grey seals became exposed so quickly, particularly at NR, when so few Scottish harbour seals had any evidence of PDV exposure after the 2002 outbreak (M. Lonergan et al. unpubl. data). Grey and harbour seals share some haul-outs, so if disease transmission occurred between species, this would be facilitated in these common areas. PDV mRNA has been detected in asymptomatic grey seals (J. A. Hammond et al. unpubl. data).

\section{CONCLUSIONS}

By autumn of both PDV outbreak years, colonies of grey seals on the west and east coasts of Scotland had similar proportions of seals whose antibody levels were consistent with exposure to PDV. Average antibody titres were greater at the IoM than at NR in both 1988 and 2002. In 2001, the adult female grey seal population comprised 2 distinct groups: older seals with a residual morbillivirus antibody titre, which in many cases still registered as seropositive and younger, uniformly seronegative seals. That young and old mothers from the 2 colonies were similarly likely to be seropositive in 2002 implies a high transmission for the disease agent. Suckling pups increased their neutralising antibody levels during lactation, reaching antibody titres that were directly related to those of their mothers. 
Acknowledgements. The authors thank the perseverance and dedication of A. Weir, who carried out all CDV neutralisation tests at Glasgow Vet School, and all those involved in fieldwork, particularly K. Bennett, S. Moss, V. Poland, S. Ruddell \& $\mathrm{S}$. Twiss. This work was carried out as part of a study on the role of grey seals as vectors for PDV from the UK's NERC, through Core support to Sea Mammal Research Unit and emergency funding to P.P.P., V.J.S., A.J.H. and H.T.

\section{LITERATURE CITED}

Appel MJG, Shek WR, Summers BA (1982) Lymphocytemediated immune cytotoxicity in dogs infected with virulent canine distemper virus. Infect Immun 37:592-600

Barrett T, Blixenkrone-Møller K, Di Guardo G, Domingo M, Duignan P, Hall AJ, Mamev L, Osterhaus ADME (1995) Morbilliviruses in aquatic mammals: report on round table discussion. Vet Microbiol 44:261-265

Blixenkrone-Møller M, Svansson V, Have P, Botner A, Neilsen J (1989) Infection studies in mink with sealderived morbillivirus. Arch Virol 106:165-170

Boyd IL, Laws RM (1962) Observations on the grey seal (Halichoerus grypus) at North Rona in 1960. Proc Zool Soc Lond 164:469-512

Carter SD, Hughes DE, Taylor VJ, Bell SC (1992) Immune responses in common and grey seals during the seal epizootic. Sci Tot Environ 115(1/2):83-92

Cornwell H, Anderson SS, Thompson PM, Mayer SJ, Ross H, Pomeroy P, Munro R (1992) The serological response of the common seal (Phoca vitulina) and the grey seal (Halichoerus grypus) to phocine distemper virus as measured by a canine distemper virus neutralisation test. Sci Tot Environ 115:99-116

Dietz R, Heide-Jørgensen M-P, Härkönen T (1989) Mass deaths of harbor seals (Phoca vitulina) in Europe. Ambio 18:258-264

Duignan PJ, Saliki JT, Staubin DJ, House JA, Geraci JR (1994) Neutralizing antibodies to phocine distemper virus in Atlantic walruses (Odobenus rosmarus rosmarus) from Arctic Canada. J Wildl Dis 30:90-94

Duignan P, Saliki JT, St Aubin D, Early S, Sadove S, House JA, Kovacs K, Geraci JR (1995a) Epizootiology of morbillivirus infection in North American harbor seals (Phoca vitulina) and gray seals (Halichoerus grypus). J Wildl Dis 31: 491-501

Duignan PJ, House C, Geraci JR, Duffy N and 7 others (1995b) Morbillivirus infection in cetaceans of the western Atlantic. Vet Microb 44:241-249

Duignan P, Duffy N, Rima BK, Geraci JR (1997) Comparative antibody response in harbour and grey seals naturally infected by a morbillivirus. Vet Immunol Immunopathol 55:341-349

Eggeling JW (1985) The Isle of May, 2nd edn. Kirkmichael, Lorien Press, Perthshire

Fogden SCL (1971) Mother-young behaviour at grey seal breeding beaches. J Zool (Lond) 164:61-92

Hall AJ (1995) Morbilliviruses in marine mammals. Tr Microbiol 3:4-8

Hall AJ, Pomeroy PP, Harwood J (1992) The descriptive epizootiology of phocine distemper in the UK during 1988/89. Sci Tot Environ 115:31-44

Harwood J, Wylie OG (1987) The seals of the Forth. Proc R Soc Edinb Sect B (Biol) 93:535-543

Harwood J, Carter SD, Hughes DE, Bell SC, Baker JR, Cornwell HJC (1989) Seal disease predictions. Nature 339:670

Harwood J, Hiby L, Thompson D, Ward A (1991) Seal stocks in Great Britain. Surveys conducted between 1986 and 1989. Nat Environ Res Council (NERC) News January:11-15

Henderson G, Trudgett A, Lyons C, Ronald K (1992) Demonstration of antibodies in archival sera from Canadian seals reactive with a European isolate of phocine distemper virus. Sci Tot Environ 115:93-98

Hewer HR (1960) Behaviour of the grey seal (Halichoerus grypus) in the breeding season. Mammals 24:400-421

Hiby AR, Duck CD, Thompson D, Hall AJ, Harwood J (1996) Seal stocks in Great Britain. Nat Environ Res Council (NERC) News January:20-22

Jensen T, van de Bildt MWG, Dietz H, Andersen TH, Hammer AS, Kuiken T, Osterhaus A (2002) Another phocine distemper outbreak in Europe. Science 297:209

Krakowka S, Hoover E, Koestner A, Ketring K (1977) Experimental and naturally occurring transplacental transmission of canine distemper virus. Am J Vet Res 38:919-922

Lawson B, Jepson P (2004) UK phocine distemper virus epizootic. Final Report to the Department of Environment Food and Rural Affairs, Institute of Zoology, London

Mangi RJ, Munyer TP, Krakowka S, Jacoby RO, Kantor FS (1976) A canine distemper model of virus-induced anergy. J Infect Dis 133:556-563

McConnell BJ, Fedak MA, Lovell P, Hammond PS (1999) Movements and foraging areas of grey seals in the North Sea. J Appl Ecol 36:573-590

McCulloch B, Krakowka S, Koestner A (1974) Experimental canine distemper virus-induced lymphoid depletion. Am J Pathol 74:155-166

Osterhaus A, Vedder E (1988) Identification of virus causing recent seal deaths. Nature 335:20

Osterhaus A, Groen J, UtydeHaag FGCM, Visser IKG, Crowther J, Bostock CJ (1989) Morbillivirus infections in European seals before 1988. Vet Rec 125:326

Pomeroy PP, Fedak MA, Anderson SS, Rothery P (1999) Consequences of maternal size for reproductive expenditure and pupping success of grey seals at North Rona, Scotland. J Anim Ecol 68:235-253

Pomeroy P, Worthington Wilmer J, Amos W, Twiss SD (2001) Reproductive performance links to fine-scale spatial patterns of female grey seal relatedness. Proc R Soc Lond B 268:711-717

Redman P, Pomeroy PP, Twiss SD (2001) Grey seal maternal attendance patterns are affected by water availability on North Rona, Scotland. Can J Zool 79:1073-1078

Ross PS, Visser IK, Broeders HW, van de Bildt MW, Bowen WD, Osterhaus AD (1992) Antibodies to phocine distemper in Canadian seals. Vet Rec 130(23):514-516

Swinton J, Harwood J, Grenfell BT, Gilligan CA (1998) Persistence thresholds for phocine distemper virus infection in harbour seal (Phoca vitulina) metapopulations. J Anim Ecol 67:54-68

Thompson D, Lonergan ME, Duck CD (in press) Harbour seal population changes in the UK. J Appl Ecol

Thompson PM, Hall AJ (1993) Seals and epizootics-what factors might affect the severity of mass mortalities? Mammal Rev 23:149-154

Thompson PM, Cornwell HJC, Ross HM, Miller D (1992) Serologic study of phocine distemper in a population of harbor seals in Scotland. J Wildl Dis 28:21-27

Thompson PM, Thompson H, Hall AJ (2002) Prevalence of morbillivirus antibodies in Scottish harbour seals. Vet Rec 151:609-610

Winters W (1981) Time dependent decreases of maternal canine virus antibodies in newborn pups. Vet Rec 108: 295-299 